\title{
Parental Influence on the emotional, moral, and social Development of Children and findings of popular psychologists.
}

\author{
Vandana Verma, MA, Med (Education) \\ Asst. Professor, Pataudi College of Education, Pataudi, Gurgaon, India.
}

\begin{abstract}
The environment plays an important role in the development of children. The paper specifically focuses on the influence parents have on the development of their children whether they are biological, adoptive, or guardian parents. In terms of the parental role in development, the paper examines how parents influence the emotional, moral, and social development of their children. As children grow up, there are many aspects of their lives which influence and affect their development and behaviors. One of the most important facets during this time period of development is the parental figures in their life. They play a large role in the social and emotional behaviors a child will possess during childhood and later in life as well. The way a parent socializes may have a slight amount to do with their genetic makeup, but due to the child's interactions with and observations of, the parents contribute more to the social and empathy related development than heredity does .When children observe their parents emotions, they feel that that is how they should be reacting as well. Parents need to take their child into consideration before themselves at times, and often they don't do that. When the parent has a problem in their life, if it doesn't directly involve the child, they should not pull them into it. Research was done and it was found that children take their parents problems into themselves and worry about it just as much as the parent, even if it doesn't involve them. This is a common problem families face during a divorce; children believe it is because of them and therefore it is their problem to deal with, even though in most cases it has nothing to do with them. That's a heavy burden for children to carry with them and brings a lot of emotional baggage that they wouldn't have to deal with if they weren't influenced by their parents' emotions. The emotions children encompass influence how they deal with social interactions as well.
\end{abstract}

\section{Parental Influence and the child Development}

Experts estimate that there are 60,000 to 100,000 genes (made up of DNA) in a human being's 46 chromosomes. A baby gets 23 chromosomes from his mother and 23 from his father. With all the possible gene combinations, one pair of parents has the potential to produce 64 trillion different children. This probably gives you an idea of how impossible it is to predict just what your baby will look like. The science of genetics is complicated, but with a short course you can get some information to guide your imagination.

Remember learning about genes and fruit flies in high school biology? Back then, you were told that the dominant gene always beats out the recessive one. Well, scientists have always known humans are more complicated than fruit flies. But in recent years, they've learned just how much more complicated.

As it turns out, most human traits are polygenic -- the result of many genes acting together. To complicate things even further, for some traits -- such as height, weight, and especially personality -environment also has a significant influence on which genes are expressed and which remain muted.

Characteristics will arise based on its inherited genes. Therefore, it is evident that parents directly influence the development of their child in the genetic sense. Once the child is born, however, the child enters into a new environment in which the parents are the sole means of survival and interaction with the world. As a result, a key question arises; to what extent do parents influence the development of their child beyond genetics? How do the environmental interactions with parents influence the development of a child? Studies show that parents greatly influence the development of their child in all areas. However, parental influence on development is most notable in the areas of psychosocial development. Furthermore, parents play a vital role in the emotional, moral, and social development of their child or children.

\section{Emotional Influence}

Emotional development includes all aspects of personality and identity development. Throughout life, one's personality and identity are greatly influenced by genes as well as environmental influences such as parents. For example, at birth, one has a particular temperament or characteristic disposition and method of approaching and reacting to situations. A child's temperament is essentially the emotional self-regulation of a child when he or she responds to situations, how sociable the child is, and its activity level. According to research, temperament is a fairly stable characteristic of an individual based mainly on heredity .However, one's temperament can be influenced and altered to a certain degree based on the interactions of the child with a 
parent. If a child with a difficult temperament has a parent with a difficult temperament, the parent theoretically will be able to address the child's temperament and make adapting to new situations and various changes easier; this is referred to as the goodness of fit between parent and child. For example, Park, Belsky, Putnam, and Cynic found that fearful and shy male toddlers who were encouraged by their parents to explore new situations became less inhibited over time. However, toddlers who were not encouraged to explore maintained their shy and fearful nature. Despite the relative stability of temperament, parental involvement does influence the development of a child.

In addition to temperament adaptations, parents influence the personality development of their child. According to Erik Erikson and his psychosocial developmental theory, individuals encounter a specific crisis at various stages of development. For example, at the first stage of development, toddlers encounter the trust versus mistrust crisis. At this stage, a child must experience enough trust in situations and relationships to establish the virtue of hope. A child at this age largely only interacts with his or her parents; therefore, they are the main source of trust and mistrust in the child's life. If parents have a trusting and supportive relationship with their child, then the child overcomes the crisis and establishes the virtue of hope. In a later stage, Erikson identifies the crisis of identity versus identity diffusion in which one must fully explore relationships and occupations and then commit in order to reach identity achievement. Erikson states that parents must allow a child to fully explore his or her options and commit on his or her own in order to obtain identity achievement. Erikson states that if parents force a child into a career or relationship, then the child will not reach identity achievement. In this sense, parental influence is pivotal to a child reaching identity achievement; if a child is not allowed a specific amount of autonomy, the child will not overcome this crisis.

Parental influence on the personality development of a child also includes the development of emotional and behavioral self-regulation. Emotional regulation, or the ability to control emotions and emotional responses, stems from the level of response and involvement of parents in a child's life. For example, parents act as a resource for their child in social referencing. When a child is placed in a fear-inducing situation, if a parent is present, the child will look toward the parent and examine facial expressions. If the parent does not show emotional distress, then the child will display less distress and more engagement in the situation. As a result of the emotional regulation and social referencing, a child also experiences a level of emotional stability.

Like emotional regulation, behavioral regulation comes about as a result of parental involvement and response to various aspects of a child's life. For example, parents who are accepting of their children, grant them more autonomy, and implement higher levels of behavioral control in terms of rules and guidelines have children who display higher levels of behavioral self-regulation, maturity, identity, and work orientation. Therefore, parents play a vital role in the development of emotional and behavioral self-regulation in their child.

It is clear that parents not only influence the development of emotional and behavioral self-regulation in their child, but they also influence the development of maturity and drive. The development of maturity and drive in children is most prevalent in academic achievement. Aunola, Nurmi, Lerkkanen, and Raku-Puttonen (2003) found in a recent study that a parent's belief in his or her child's academic success influenced the child's success and drive to excel. Therefore, if the parent believed the child was going to be successful academically, he or she often became more focused on success and, as a result, achieved higher success. In addition, the study found that, in the mathematical area, if children were task-focused and had a drive to succeed then their mathematical scores would increase. Parents who played an active part in their child's life and advocated certain success in academics positively influenced the development of drive and success in their children. Overall, parents who actively participate in their child's development in a responsive manner will positively influence the emotional development of their child.

\section{Moral Influence}

Moral development, like emotional development, results from the positive influence of parents on a child. According to Lawrence Kohlberg, parental participation in moral development is not necessary for one to reach a high level of moral reasoning because schools and other settings can provide similar moral environments. However, Hoffman (1983, as cited in Bornstein, 2002) states that disciplinary encounters with parents are crucial for the internalization of moral standards. When a parent intervenes in a child's negative behavior in an attempt to correct the behavior and then disciplines the child, the parent is attempting to help the child internalize moral standards. Hoffman states that in order for the disciplinary actions to lead to internalization, the parents must use inductive techniques in which they point out the effect of the child's behavior on others (1983, as cited in Bornstein, 2002). In terms of moral judgment, parents who encourage their child to actively participate in discussion and decision-making with regards to him or herself and the family are more likely to help their child function at a higher level of moral reasoning (Bornstein, 2002). Parents also facilitate moral growth and high levels of moral reasoning when they draw out the child's opinion and reasoning with appropriate questions and paraphrasing to check for an understanding of the situation. However, the probing must be done with support and attentiveness in order for it to effectively influence moral. Overall, 
parents who use inductive reasoning, stimulate moral reasoning with moral discussions, and are supportive and encourage autonomous thinking will have a child who functions at a higher level of moral reasoning.

\section{Social Influence}

The social development of a child is influenced by parental involvement similar to emotional and moral development. The social relationship a child has with his or her parents directly correlates with the relationships and social behavior the child will have throughout life. As a result, the attachment a child has with his or her parents is pivotal to his or her social development. Ainsworth has classified three main forms of attachment a child has with his or her parents: secure, avoidant, and ambivalent (Papalia et al., 2002). In a secure attachment, a child is upset when the parent leaves and happy when the parent returns. An avoidant attachment is characteristic of a child not being upset when the parent comes or goes. A child with an ambivalent attachment to his or her parent is upset when the parent leaves and will go back to him or her when the parent returns but the child is resistant and hard to comfort. A child who has a secure attachment with his or her parents is more resilient, empathetic, and self-knowledgeable, has a higher self-esteem, and is more curious (Papalia et al., 2002).

The attachment relationships a child forms as a baby influence relationships the child has throughout the remainder of his or her life. For example, Sternberg (1987, as cited in Papalia et al., 2003) has identified a triangular theory of love composed of three main components: passion, intimacy, and commitment. An ideal relationship, according to Sternberg, will consist of all three components over time; individuals in a relationship with all three components will have consummate love. People who did not have secure relationships as children will not be able to have consummate love. Rather, one who has ambivalent attachments will have passion and commitment in relationships but not intimacy, and one who has avoidant attachments will only have passion in relationships (Papalia et al., 2003). In addition, the form of attachment one has will influence peer relations as well as romantic relations. Individuals who have secure attachments to parents and other family members will transfer this level of security, trust, and support to peer relationships as well.

The relationship between parents and their child also influences different aspects of his or her social development. For example, when a child is very young, the child will look to parents to see how to respond to ambiguous situations as a form of social referencing. In this manner, the child learns proper social behavior from imitating the behavior of the parents .Specifically, a child will learn how to address conflict from the influence of his or her parents. Miller, DiIorio, and Dudley (2002) found that children whose parents were responsive, controlling, and involved were less likely to respond to conflict with violence than children whose parents were not involved as much. The children who were likely to respond to conflict with violence had parents who were inconsistent in discipline approaches and did not respond with adequate punishment (Miller et al., 2002).

In addition to directly influencing the social development of their child, parents influence the people the child interact with and the child's peer group. Parke and Bhavnagri (1989, as cited in Collins, Maccoby, Steinberg, Hetherington, \& Bornstein, 2000) found that parents influence their child's peer experience by propelling their child toward certain peers through managing the child's social activities. In addition, they found that parents influence the child's attitudes, values, personality, and motives which therefore affect the child's interactions with peers. From his or her initial experiences with peers, a child then becomes friends with peers who are similar in school achievement, activities, and personality traits (Collins et al., 2000).

A final aspect of a child's social development that parents influence is their child's response to peer pressure. A child whose parents are responsive and demanding is less influenced by peer pressure to partake in antisocial behavior such as using drugs, alcohol, and participating in sexual relations (Collins et al., 2000). In addition, these children are more likely to be influenced by prosocial behavior such as pressure to do well in school. Lastly, peer relations do not alter enduring personality traits and values such as religion, occupational goals, and educational plans (Collins et al., 2000). Furthermore, responsive and demanding parents instill traits and qualities in their children that inhibit their susceptibility to negative forms of peer pressure.

Throughout each form of psychosocial development, parents play a vital role in the positive development of their child. Parents who influence the development of their child in a positive manner tend to have particular qualities and characteristics. These parents tend to be responsive, demanding, accepting and emphasize discussion and interaction. According to Baumrind, these parents have the characteristics of an authoritative parent (1991, as cited in Papalia et al., 2003). Therefore, it can be concluded that parents who are generally authoritative are those who influence the development of their child in the best manner.

The research clearly identifies some characteristic behaviors of parents and how these behaviors influence the development of their child; however, there are some issues that are not present. In the future, more research should be completed to exhaust the topic of parenting and to assess how much parenting directly influences the development of a child. For example, more research should be done on a child's view toward sexuality and sexual activities. In current society, sexual relations occur earlier in life; therefore, it is important 
that parents know how to positively influence their child on these issues. In addition, more research should be done on the moral development of a child. For example, research should examine how parents influence the higher levels of morality in their child as well as the strength of the child's morals and values.

\section{Conclusion}

It is quite evident that parents have great influence on the development of their child. In the emotional sense, a positive parental influence can help a child establish a healthy personality and reach identity achievement. Parents also aid in the development of their child's moral reasoning and judgment skills through supportive discussions and conversations. Lastly, I can say a closer, secure relationship between the child and parents influences the social behavior of the child in the future. A secure attachment between the parents and the child positively influences peer relations and romantic relations. Therefore, the genetic component of the child that the parents provide is only one aspect of their influence on the child's development. The environmental aspect of development is especially important in the psychosocial development of a child.

\section{References}

[1]. Cytryn, L., \& McKnew, D.H.. (1996). Growing Up Sad. New York, NY: W.W. Norton \& Company.

[2]. Aunola, K., Nurmi, J., Lerkkanen, M., \& Rasku-Puttonen, H. (2003). The Roles of Achievement-Related Behaviors and Parental Beliefs in Children's Mathematical Performance. Education Psychology, 23 (4), 403-421.

[3]. Bornstein, M. H. (Ed.). (2002). Handbook of Parenting: Practical Issues in Parenting (2 ${ }^{\text {nd }}$ ed., Vol. 5). Mahwah, NJ: Lawrence Erlbaum Associates, Inc.

[4]. Collins, W. A., Maccoby, E. E., Steinberg, L., Hetherington, E. M., \& Bornstein, M. H. (2000). Contemporary Research on Parenting: The Case for Nature and Nurture. American Psychologist, 55 (2), 218-232.

[5]. Hay, I., \& Ashman, A. F. (2003). The Development of Adolescents' Emotional Stability and General Self-Concept: the interplay of parents, peers, and gender. International Journal of Disability, Development, and Education, 50:1, 78-91.

[6]. Miller, J. M., DiIorio, C., \& Dudley, W. (2002). Parenting Style and Adolescent's Reaction to Conflict: Is There a Relationship? Journal of Adolescent Health, 31, 463-468.

[7]. Papalia, D. E., Olds, S. W., \& Feldman, R. D. (2002). A Child's World: Infancy Through Adolescence (9 ${ }^{\text {th }}$ ed.). New York, NY: McGraw Hill.

[8]. Papalia, D. E., Olds, S. W., \& Feldman, R. D. (2003). Psychology: Adolescent and Adult Development (9 ${ }^{\text {th }}$ ed.). New York, NY: McGraw Hill-Primis.

[9]. Porretto, Denise : (American baby) .

[10]. Sharpe. Kelsey,Parental role in development, Creighton. 